\title{
Aplikasi Perhitungan PPH 21 Dan PPH 26 Karyawan Berbasis Web
}

\author{
Yulia $^{1}$, Novita Ganiar Anggraini ${ }^{2}$, Lisnawanty ${ }^{3}$
}

\begin{tabular}{|c|c|}
\hline Info Artikel & ABSTRACT \\
\hline $\begin{array}{ll}\text { Diterima } & \text { Juni 12, } 2020 \\
\text { Revisi } & \text { Juli 16, } 2020 \\
\text { Terbit } & \text { September 30,2020 }\end{array}$ & $\begin{array}{l}\text { Income Tax PPh 21/26 is a tax on I ncome in the form of salaries, } \\
\text { wages, honoraria, allowances, and other payments in whatever } \\
\text { name and form in connection with work or services. There are also } \\
\text { many taxpayers who do not understand how to calculate Income } \\
\text { Tax } 21 / 26 \text { on the income they get from their work. therefore, the } \\
\text { public must further increase self-awareness to pay taxes and report }\end{array}$ \\
\hline $\begin{array}{l}\text { Keywords: } \\
\text { PPh } 21 / 26 \\
\text { Employee } \\
\text { Accounting Information } \\
\text { System } \\
\text { Web Application }\end{array}$ & $\begin{array}{l}\text { also useful for taxpayers in the tax reporting process. The purpose } \\
\text { of this research is to know and analyze the procedure for } \\
\text { calculating the PPh } 21 / 26 \text { employee's income tax calculation } \\
\text { system and designing and building an application for calculating } \\
\text { the PPh } 21 / 26 \text { employee's income tax. With the application for } \\
\text { calculating employee income tax article } 21 / 26 \text {, it will make it easier } \\
\text { for employees to make tax payment transactions. In the PPh } 21 / 26 \\
\text { Calculation Application the system displays tax payment data, } \\
\text { employee data and user data. In making it, the author uses the } \\
\text { Codeigniter Framework application with the hypertext } \\
\text { preprocessor (PHP) programming language. This program also } \\
\text { uses several supporting software in making the Web such as Xampp } \\
\text { as a local server, Google Chrome as a Web browser and Mysql as } \\
\text { a database server. }\end{array}$ \\
\hline
\end{tabular}

\section{Identitas Penulis:}

Yulia $^{1}$, Novita Ganiar Anggraini ${ }^{2}$, Lisnawanty ${ }^{3}$

Universitas Bina Sarana Informatika Program Studi Sistem Informasi Akuntansi Kampus Pontianak Jalan Abdurrahman Saleh No.18 A Pontianak

Email: yulia.yla@bsi.ac.id ${ }^{1}$, novitaganiar0201@gmail.com², lisnawanty.lsy@bsi.ac.id 3

\section{PENDAHULUAN}

Pajak Penghasilan menurut Undang-undang Perpajakan Nomor 38 Tahun 2008 pasal 4 ayat 1 adalah "Setiap tambahan kemampuan ekonomis yang diterima atau diproleh Wajib Pajak, baik yang berasal dari Indonesia maupun dari luar Indonesia, yang dapat dipakai untuk konsumsi atau untuk menambah kekayaan Wajib Pajak yang bersangkutan, dengan nama dan dalam bentuk apapun".

Ketentuan pasal 21 Undang-undang Pajak Penghasilan (PPh) mengatur tentang pembayaran dalam tahun berjalan melalui pemotongan pajak atas penghasilan yang diterima oleh wajib pajak dalam negeri sehubungan dengan pekerjaan, jasa dan kegiatan tersebut. Terkait administrasi perpajakan, setiap wajib pajak harus melaporkan perhitungan jumlah pajak yang dibebankan kepada wajib pajak yaitu pajak penghasilan. Pelaporan ini disampaikan dalam bentuk Surat Pemberitahuan Tahunan (SPT) Wajib Pajak Orang Pribadi. Dalam pelaksanaan tersebut kesadaran masyarakat dalam melaporkan SPT masih sangatlah kurang.

Wajib Pajak(WP) di Indonesia sendiri masih rendah dalam hal kesadaran untuk membayar pajak. Hal ini dikarenakan kebanyakan dari mereka belum mengerti tentang bagaimana perhitungan Pajak PPh 21 dan PPh 26 Karyawan atas penghasilan yang mereka dapatkan dari pekerjaannya. Untuk beberapa jenis pekerjaan, pemotongan Pajak Penghasilan (PPh) seorang pegawai atau karyawan di sebuah perusahaan/instansi dilakukan oleh pemberi kerja [1]. 
Berdasarkan hal tersebut penulis membuat sebuah aplikasi yang dapat digunakan banyak user atau pengguna media online Berbasis Web untuk mempermudah wajib pajak dalam menghitung pajak penghasilan karyawan. Dengan adanya aplikasi tersebut wajib pajak mengetahui tentang cara menghitung pajak penghasilan dan berguna bagi wajib pajak dalam proses pembayaran dan pelaporan SPT tahunan.

\section{METODE}

Jenis penelitian ini merupakan jenis penelitian yang menggunakan metode deskriptif dengan pendekatan kualitatif, yang bertujuan untuk memberikan gambaran secara objektif tentang keadaan sebenarnya dari objek yang diteliti. Penelitian ini dilakukan dengan cara mendeskripsikan masalah yang telah diidentifikasi pada saat melakukan penelitian.

\subsection{Teknik Pengumpulan Data}

Teknik pengumpulan data berfungsi sebagai cara untuk mengumpulkan data-data yang berkaitan dengan penulisan. Teknik pengumpulan data yang digunakan, terdiri dari observasi, wawancara dan studi pustaka. Adapun penjelasan dari teknik pengumpulan data yang digunakan, diuraikan sebagai berikut:

1. Observasi

Penulis dengan cara melakukan pengamatan pada objek yang diteliti terhadap data-data perhitungan $\mathrm{PPh}$ 21 dan PPh 26 Karyawan serta menganalisa sistem yang dibutuhkan untuk mengetahui dari sistem tersebut. Fokus Penelitian pada Perhitungan PPh 21 dan PPh 26 Karyawan ini adalah menghitung laporan pajak karyawan, Rekap gaji, tunjangan dan kompensasi serta pembayaran lain sehubungan dengan pekerjaan, jasa, atau kegiatan. Metode ini dilakukan dengan menyebarkan kuesioner melalui google form.

2. Kuesioner

Penulis melakukan suatu metode dengan cara menyebarkan kuesioner melalui google form.

3. Studi Pustaka

Studi pustaka digunakan untuk mendukung penulisan jurnal ini landasan teori diambil dari referensireferensi dari buku dan jurnal peneliti terdahulu.

\subsection{Metode Pengembangan Software}

Metode pengembangan software yang digunakan dalam melakukan penelitian ini menggunakan adalah model waterfall. Model waterfall adalah "Metode air terjun menyediakan pendekatan alur hidup perangkat lunak secara sekuensial atau terurut dimulai dari analisa, desain, pengkodean, pengujian, dan pendukung (support)" [3]. Metode pengembangan software dengan model waterfall ini dibagi menjadi lima (5) tahapan terdiri dari:

1. Analisis kebutuhan perangkat lunak

Dalam tahap pertama perlu menganalisa kebutuhan perangkat lunak yang akan dibuat. Untuk itu perlu diketahui permasalahan yang dialami oleh perusahaan dalam pengelolaan keuangan. Lalu dibuatlah analisa kebutuhan software.

2. Desain

Dalam tahapan desain ini, penulis membuat rancangan basis data, pemodelan rancangan menggunakan unified modeling language (UML), perancangan dan perancangan tampilan antar muka.

3. Pembuatan Kode Program

Pengkodean (coding) program menggunakan sublime text sebagai Web editor bahasa pemrograman hypertext preprocessor (PHP) dan hypertext markup language (HTML) berdasarkan logika yang dirancang pada tahapan desain.

4. Pengujian

Tahapan pengujian menentukan apakah sistem atau perangkat lunak yang telah dibuat sudah sesuai dengan kebutuhan pengguna atau belum dengan metode blackbox testing sebagai media pengujian.

\section{HASIL}

\subsubsection{Analisis Kebutuhan Software}

Analisa kebutuhan software merupakan langkah awal. Kondisi, kriteria, syarat atau kemampuan yang harus dimiliki oleh perangkat lunak untuk menentukan gambaran perangkat yang dihasilkan ketika pengembang melaksanakan sebuah proyek pembuatan perangkat lunak atau untuk memenuhi apa yang disyaratkan dan diinginkan oleh pemakai.

\subsubsection{Analisa Kebutuhan Fungsional}

Berikut ini adalah analisa kebutuhan pengguna akan aplikasi perhitungan $\mathrm{PPh} 21$ dan $\mathrm{PPh} 26$ Karyawan: 


\section{Admin}

a. Admin dapat melakukan login.

b. Admin dapat mengakses menu beranda.

c. Admin dapat mengakses master data.

1) Admin dapat mengakses data pengguna.

2) Admin dapat mengakses data karyawan.

3) Admin dapat mengakses data jabatan.

4) Admin dapat mengakses data golongan.

d. Admin dapat mengakses data pembayar pajak.

e. Admin dapat mengakses laporan.

f. Admin dapat melakukan logout.

2. Karyawan

a. Karyawan dapat melakukan login.

b. Karyawan dapat mengakses beranda.

c. Karyawan dapat mengakses menu profil.

d. Karyawan dapat mengakses menu pembayaran.

e. Karyawan dapat melakukan logout.

\subsubsection{Use Case Diagram}

Use case diagram merupakan pemodelan untuk menggambarkan kelakuan sistem yang akan dibuat, menggambarkan proses bisnis dan juga urutan aktivitas yang ada dalam sebuah proses dan mendeskripsikan sebuah interaksi antara satu atau lebih aktor dengan sistem yang akan dibuat. Use case diagram digunakan untuk mengetahui fungsi apa saja yang ada didalam sebuah sistem dan siapa saja yang menggunakan fungsifungsi tersebut.

Use case diagram beranda sistem Berikut ini adalah use case diagram beranda pada Aplikasi Perhitungan PPh 21 dan PPh 26 Karyawan Berbasis Web.

1. Beranda Admin

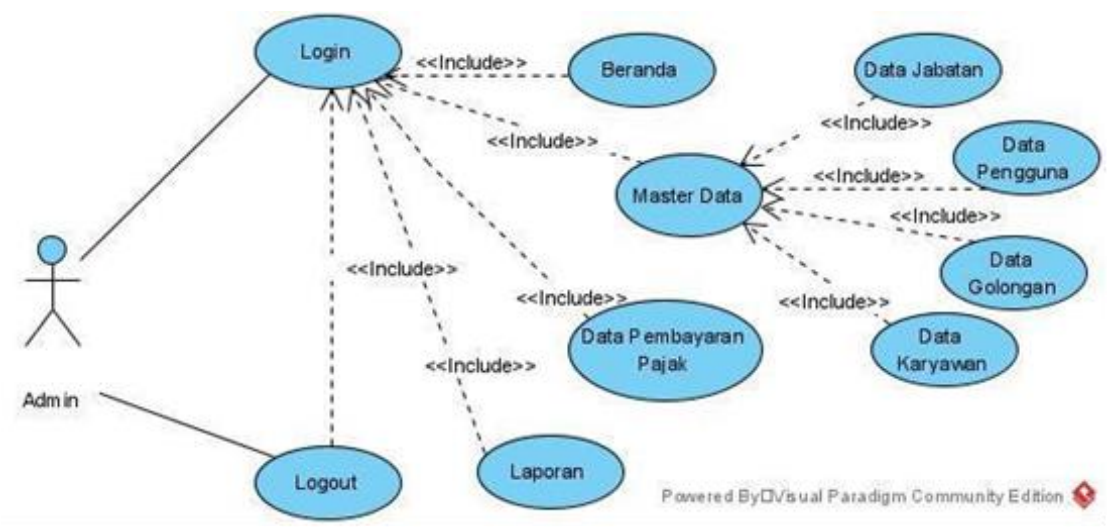

Sumber : Hasil Penelitian (2020)

Gambar 1. Use Case Diagram Beranda Admin

Pada beranda admin dapat melakukan pengolahan data yang ada di beranda mulai dari mengelola menu master data, mengakses menu data pengguna dan data karyawan. Admin juga dapat mengakases menu data pembayaran pajak, mengakses laporan dan logout.

2. Beranda Karyawan 


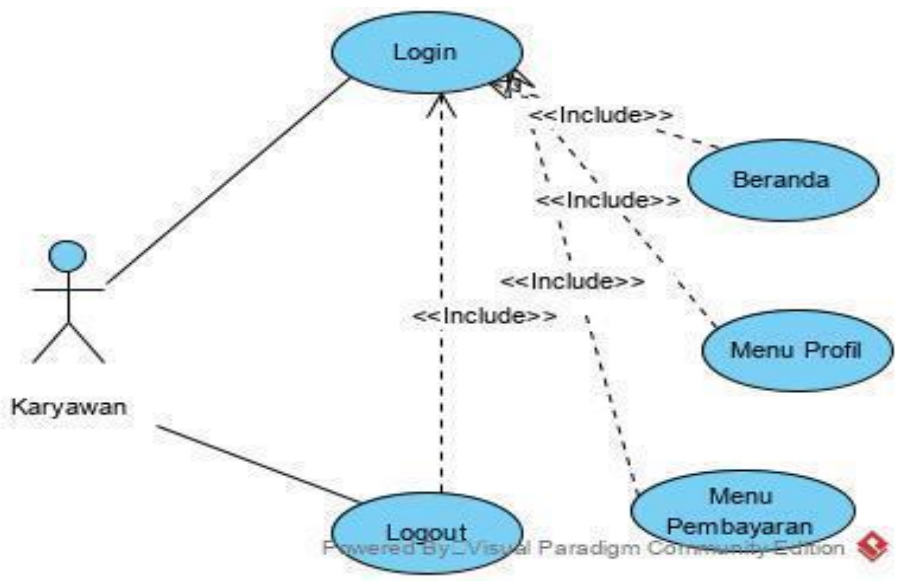

Sumber : Hasil Penelitian (2020)

Gambar 2. Use Case Diagram Beranda Karyawan

Pada beranda karyawan, karyawan dapat melakukan login dan mengakses menu menu profil, melakukan pembayaran dan mencetak laporan hasil dari transaksi pembayaran pajak dan juga dapat melakukan logout.

\subsubsection{Activity Diagram}

Activity diagram ini menggambarkan tentang aktifitas yang terjadi pada sistem. Berikut Activity diagram tampilan data pengguna pada aplikasi perhitungan PPh 21 dan PPh 26 Karyawan Berbasis Web.

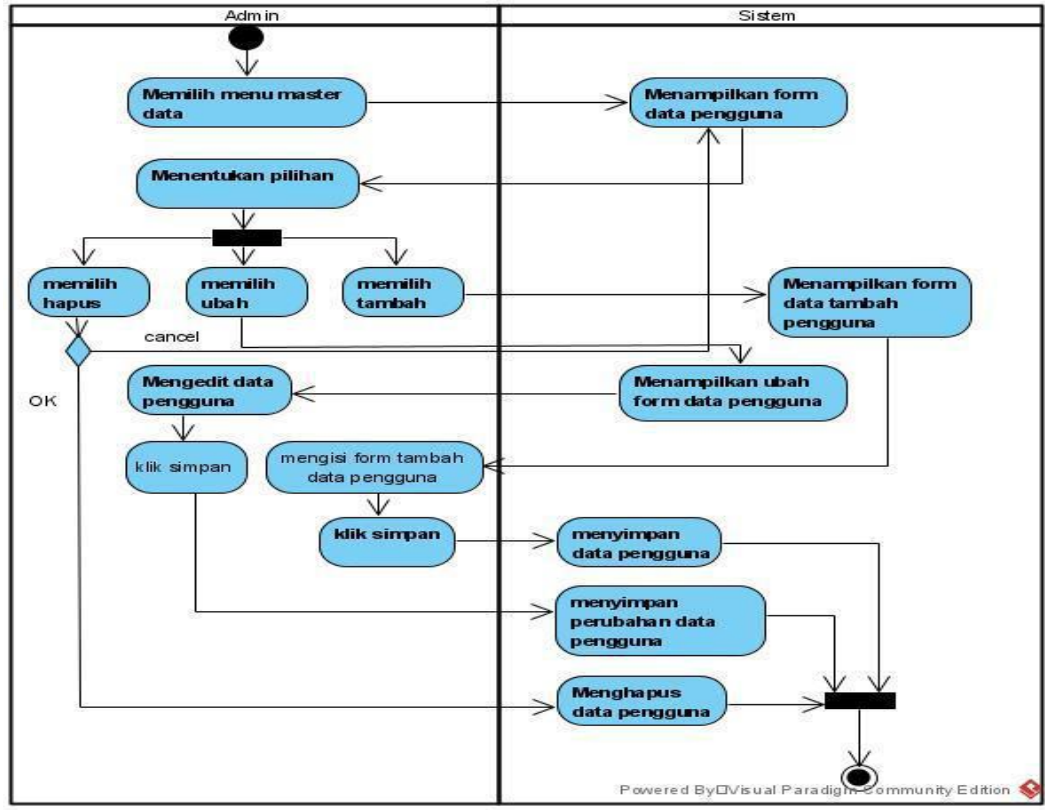

Sumber : Hasil Penelitian (2020)

Gambar 3. Activity Diagram Tampilan Data Pengguna

Pada activity diagram tampilan data pengguna sistem ini menjelaskan, dimana admin dapat menambah, mengubah dan menghapus data yang ada didalam sistem.

\subsubsection{Entity Relationship Diagram (ERD)}

Entity Relationship Diagram (ERD) menjelaskan hubungan antara data dalam basis data yang terdiri dari objek dasar yang mempunyai hubungan atau relasi antar objek tersebut. Berikut ini adalah ERD Aplikasi perhitungan PPh 21 dan PPh 26 Karyawan Berbasis Web : 


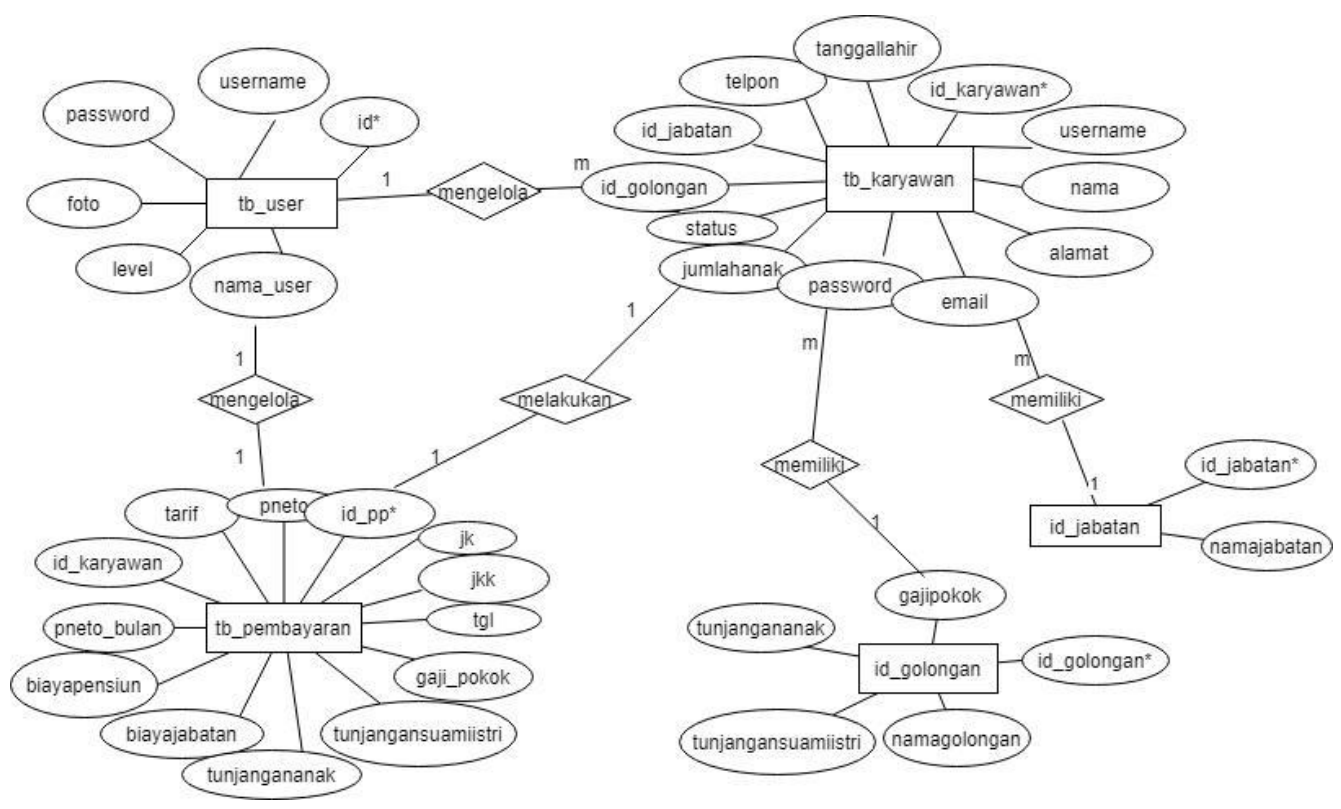

Sumber : Hasil Penelitian (2020)

\section{Gambar 4. Entity Relationship Diagram (ERD)}

Pada Gambar 4 merupakan bentuk dari kebutuhan fungsional yang akan dijadikan tabel-tabel pada database sehingga bisa dibuatkan sebuah aplikasi yang disebut dengan aplikasi Perhitungan PPh 21 dan PPh 26 Karyawan Berbasis Web.

\subsubsection{Logical Record Structure (LRS)}

Jika dilihat dari salah satu teori (LRS) Logical Relationship Structure merupakan hasil dari Entity Relationship (ER) berserta atributnya sehingga bisa terlihat adanya suatu hubungan-hubungan antara entitas [3]. Berikut ini merupakan LRS dari Aplikasi Perhitungan PPh 21 dan PPh 26 Karyawan Berbasis Web :

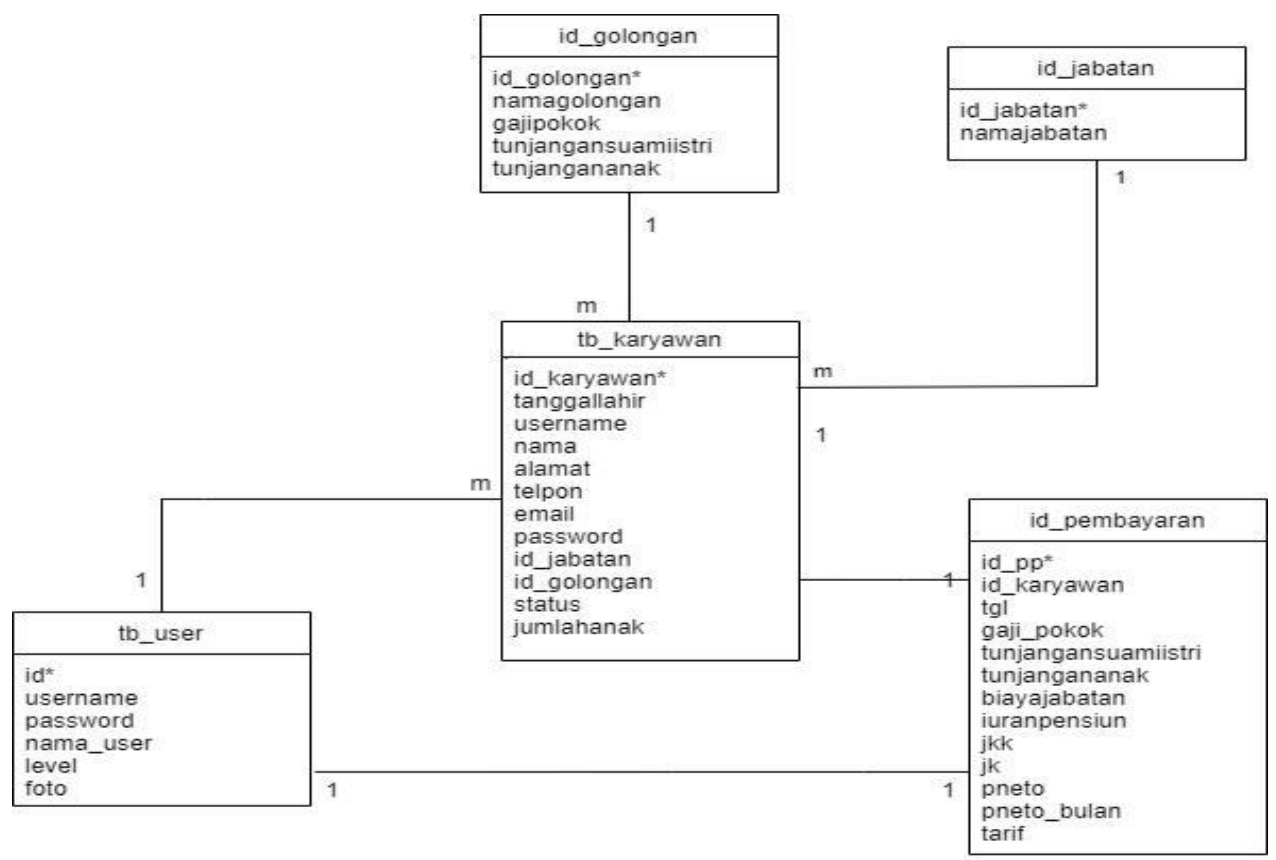

Sumber: Hasil Penelitian (2020)

Gambar 5. Logical Record Structure (LRS) 


\subsubsection{Sequence Diagram}

Sequence Diagram merupakan satu dari diagram - diagram yang ada pada UML, Sequence Diagram ini adalah diagram yang menggambarkan kolaborasi dinamis antara sejumlah object. Kegunaannya untuk menunjukkan rangkaian pesan yang dikirim antara object juga interaksi antara object.

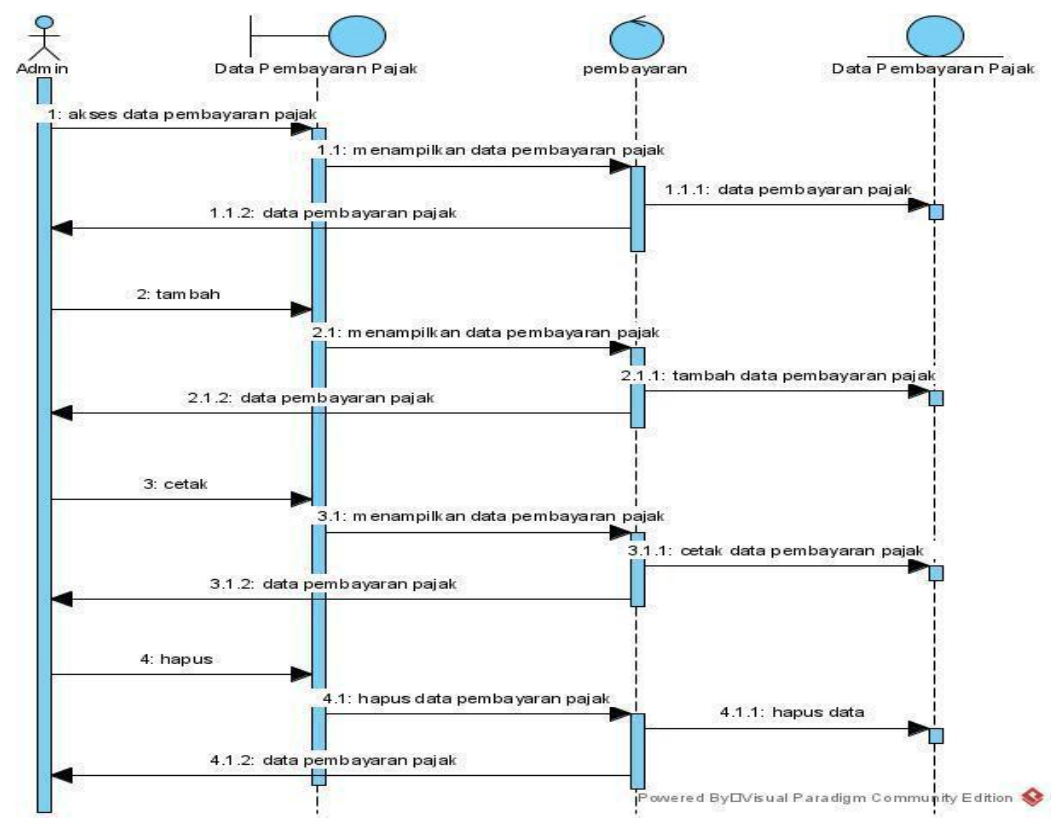

Sumber : Hasil Penelitian (2020)

Gambar 6. Sequence Diagram Data Pembayaran Pajak Pada Perhitungan PPh 21 dan PPh 26 Karyawan

Pada Sequence Diagram data pembayaran pajak dimana diagram mengambarkan admin dapat mengakses menu tambah, hapus dan juga dapat mencetak data pembayaran pajak yang ada pada pada sistem. pada sistem ini hanya admin yang dapat melihat dan mengelola menu.

\subsection{User Interface}

User Interface adalah bentuk tampilan yang berhubungan langsung dengan pengguna dan memiliki fungsi untuk menghubungkan antara pengguna dengan sistem operasi sehingga komputer dapat dioperasikan. 1. User Interface Form Login Admin

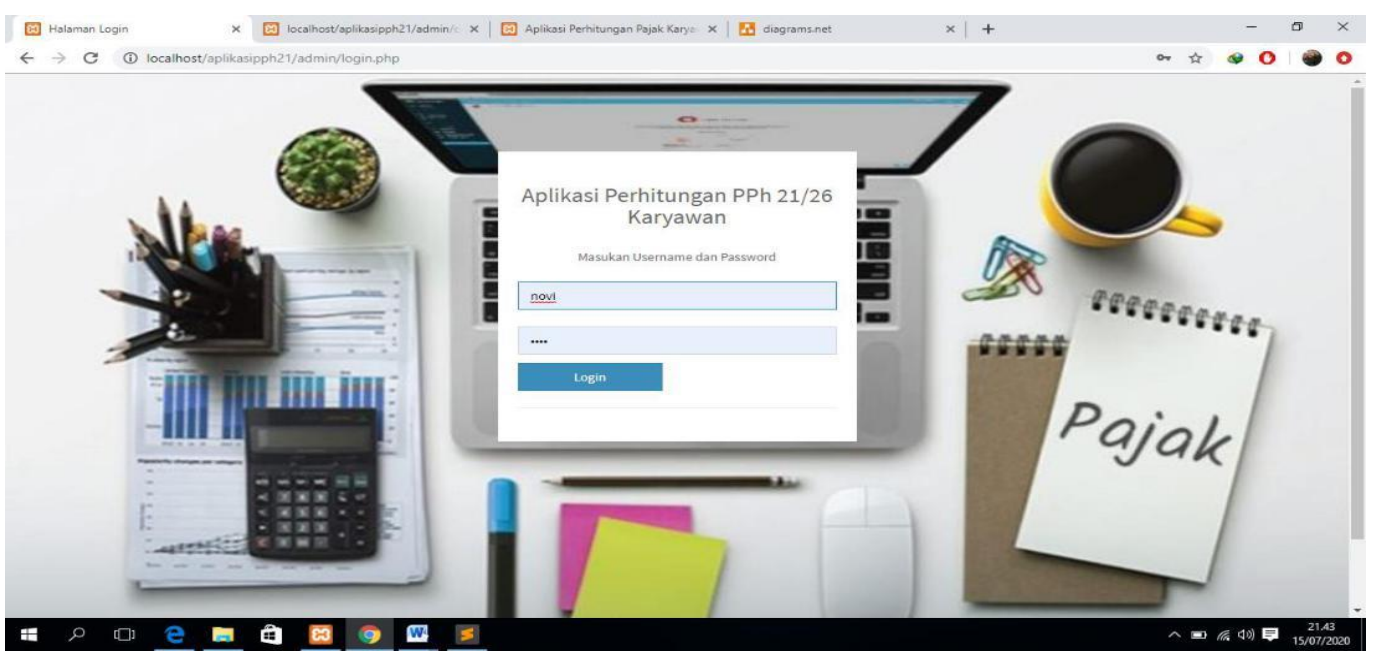

Sumber : Hasil Penelitian (2020)

Gambar 7. User Interface Form Login Admin 
2. User Interface Form Login Karyawan

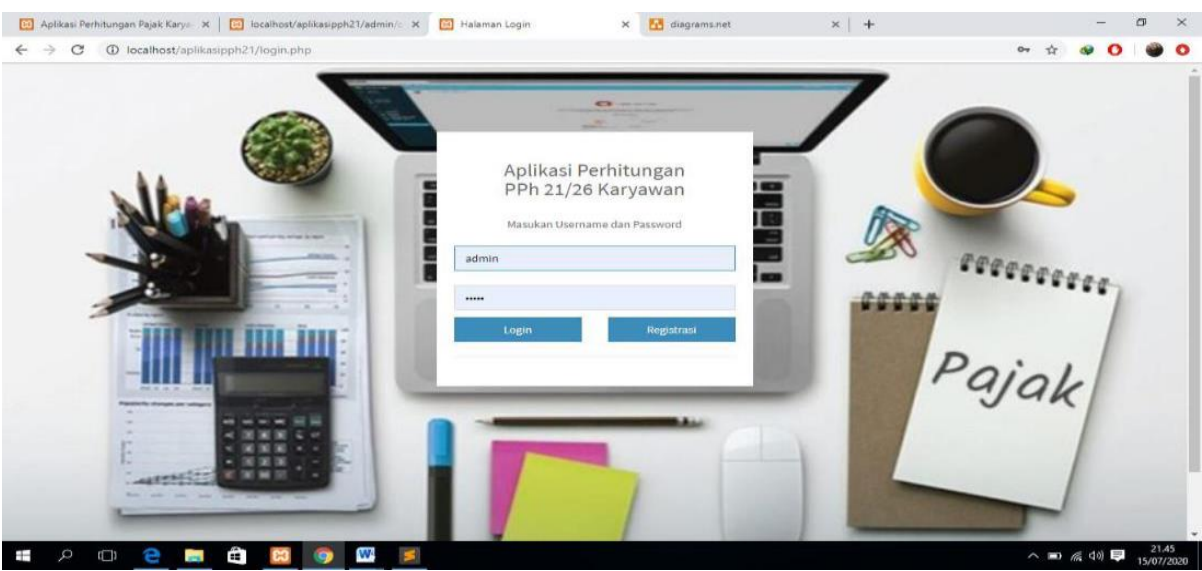

Sumber : Hasil Penelitian (2020)

Gambar 8. User Interface Form Login Karyawan

3. User Interface Beranda Admin

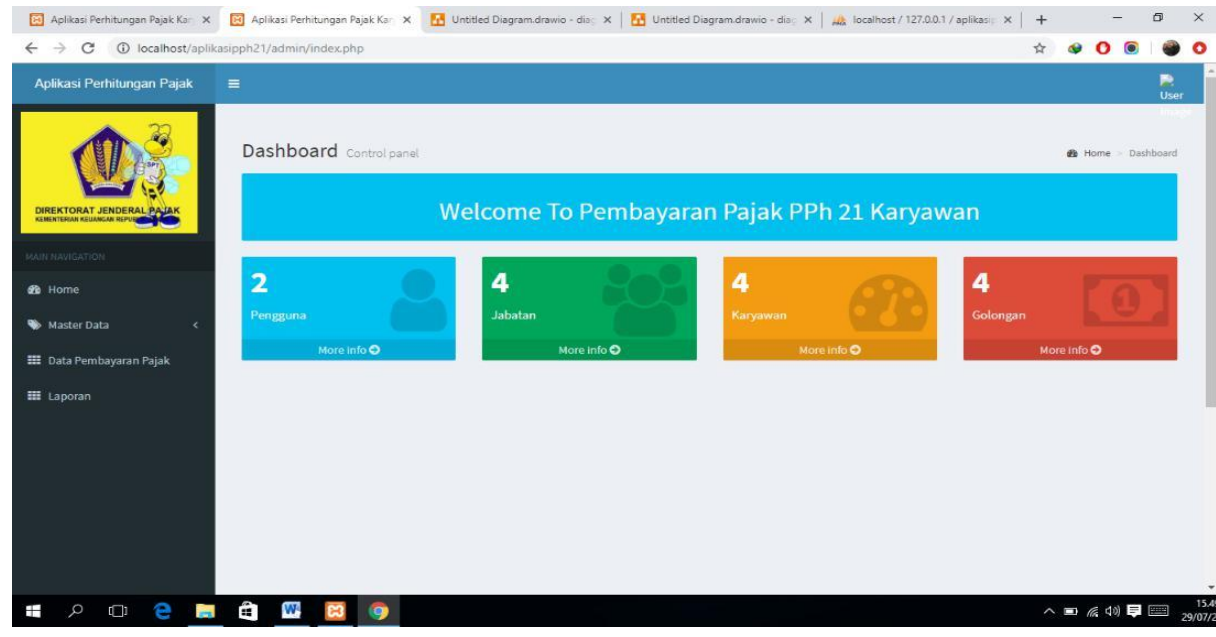

Sumber : Hasil Penelitian (2020)

Gambar 9. User Interface Beranda Admin

4. User Interface Data Karyawan

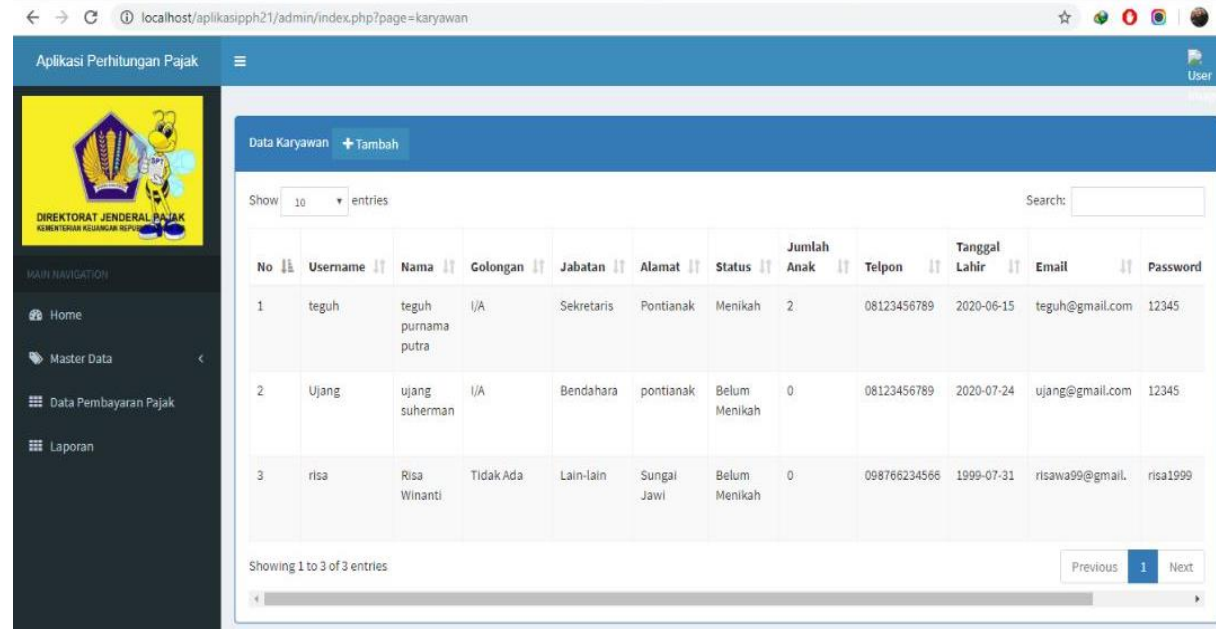

Sumber : Hasil Penelitian (2020)

Gambar 10. User Interface Data Karyawan 
5. User Interface Data Pembayaran Pajak

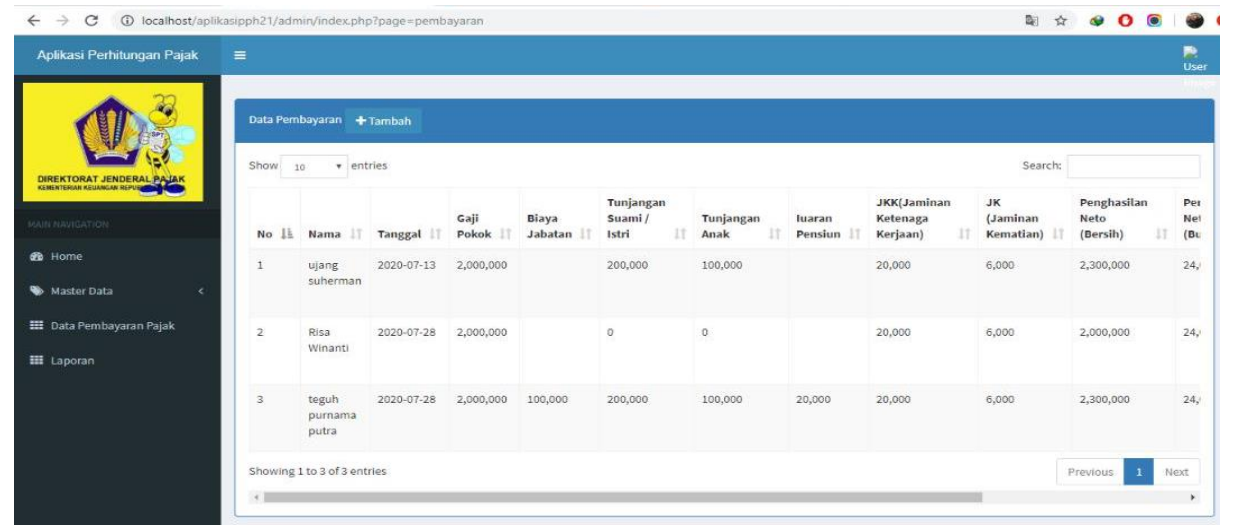

Sumber : Hasil Penelitian (2020)

Gambar 11. User Interface Data Pembayaran Pajak

6. User Interface Cetak Data Pembayaran Pajak

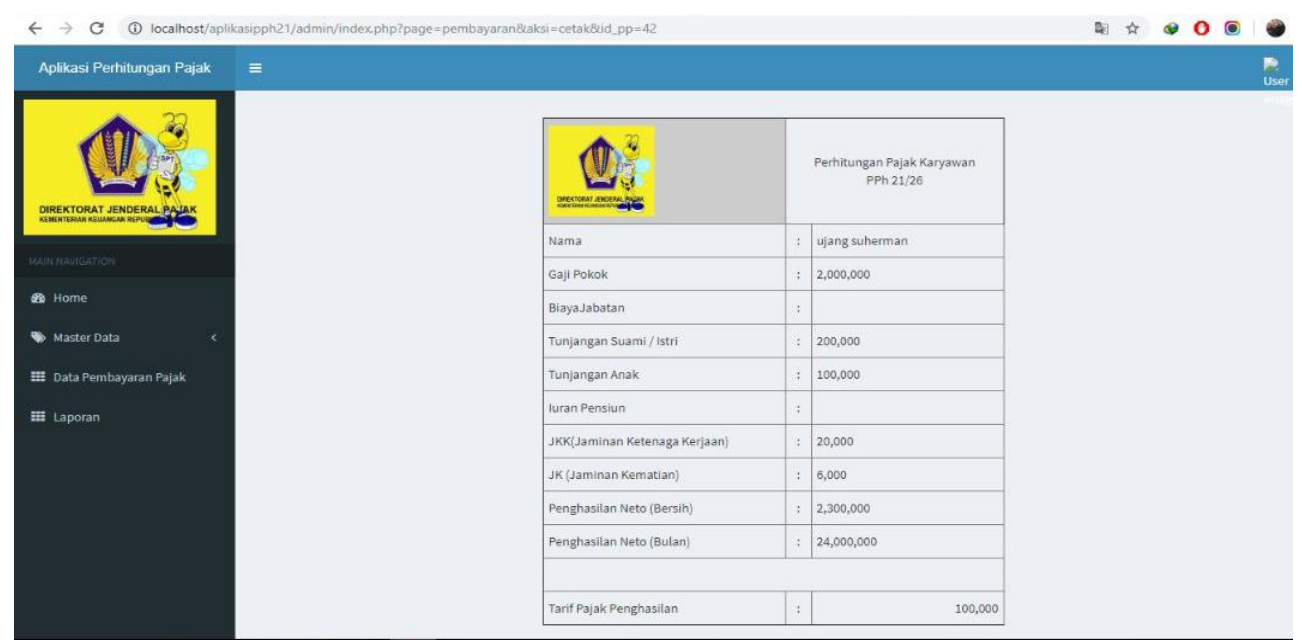

Sumber : Hasil Penelitian (2020)

Gambar 12. User Interface Cetak Data Pembayaran Pajak

7. User Interface Laporan

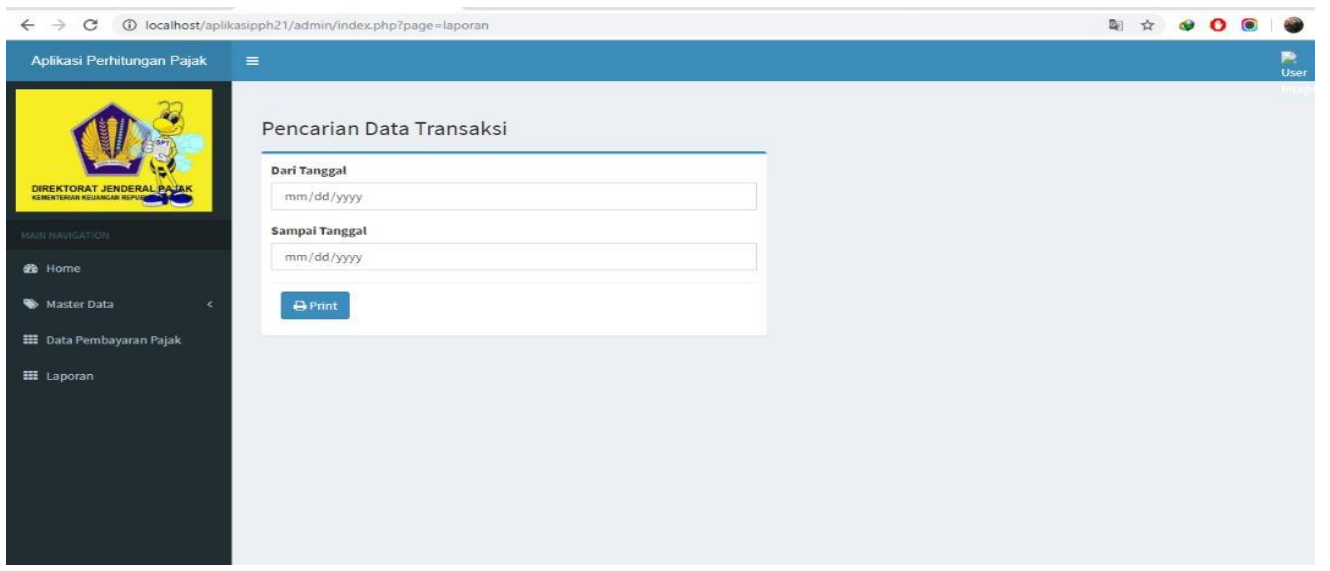

Sumber : Hasil Penelitian (2020)

Gambar 13. User Interface Cetak Data Pembayaran Pajak 


\subsection{Blackbox Testing}

Blackbox testing adalah pengujian yang dilakukan dengan mengamati hasil eksekusi melalui data uji dan memeriksa fungsional dari perangkat lunak. Berikut merupakan blackbox testing sistem informasi penjualan dan pembelian.

Tabel 1. Hasil Pengujian Blackbox Testing Form Data Pembayaran Pajak

\begin{tabular}{|c|c|c|c|c|c|}
\hline 1 & $\begin{array}{l}\text { Tambah Data } \\
\text { pembayaran pajak (data } \\
\text { yang diinput tidak } \\
\text { lengkap, kemudian klik } \\
\text { simpan) }\end{array}$ & $\begin{array}{l}\text { Nama Karyawan : (Vita) } \\
\text { Alamat : (kosong) } \\
\text { No. HP : (kosong) }\end{array}$ & $\begin{array}{l}\text { Sistem akan } \\
\text { menampilkan pesan } \\
\text { "Selamat Data Berhasil } \\
\text { Disimpan" pada data } \\
\text { yang belum diisi }\end{array}$ & $\begin{array}{c}\text { Sesuai } \\
\text { Harapan }\end{array}$ & Valid \\
\hline 2 & $\begin{array}{l}\text { Tambah Data } \\
\text { pembayaran pajak (data } \\
\text { yang diinput tidak } \\
\text { lengkap, kemudian klik } \\
\text { simpan) }\end{array}$ & $\begin{array}{l}\text { Nama Karyawan : } \\
\text { (kosong) } \\
\text { Alamat : (Jl. A. Yani) } \\
\text { No. HP : (kosong) }\end{array}$ & $\begin{array}{l}\text { Sistem akan } \\
\text { menampilkan pesan } \\
\text { "Selamat Data Berhasil } \\
\text { Disimpan" pada data } \\
\text { yang belum diisi }\end{array}$ & $\begin{array}{c}\text { Sesuai } \\
\text { Harapan }\end{array}$ & Valid \\
\hline 3 & $\begin{array}{l}\text { Tambah Data } \\
\text { pembayaran pajak (data } \\
\text { yang diinput tidak } \\
\text { lengkap, kemudian klik } \\
\text { simpan) }\end{array}$ & $\begin{array}{l}\text { Nama Karyawan : } \\
\text { (kosong) } \\
\text { Alamat : (kosong) } \\
\text { No HP : (082254783105) }\end{array}$ & $\begin{array}{l}\text { Sistem akan } \\
\text { menampilkan pesan } \\
\text { "Selamat Data Berhasil } \\
\text { Disimpan" pada data } \\
\text { yang belum diisi }\end{array}$ & $\begin{array}{c}\text { Sesuai } \\
\text { Harapan }\end{array}$ & Valid \\
\hline 4 & $\begin{array}{l}\text { Tambah Data } \\
\text { pembayaran pajak (data } \\
\text { yang diinput tidak } \\
\text { lengkap, kemudian klik } \\
\text { simpan) }\end{array}$ & $\begin{array}{l}\text { Nama Karyawan : (Vita) } \\
\text { Alamat : (Jl. A. Yani) } \\
\text { No HP : (kosong) }\end{array}$ & $\begin{array}{l}\text { Sistem akan } \\
\text { menampilkan pesan } \\
\text { "Selamat Data Berhasil } \\
\text { Disimpan" pada data } \\
\text { yang belum diisi }\end{array}$ & $\begin{array}{c}\text { Sesuai } \\
\text { Harapan }\end{array}$ & Valid \\
\hline 5 & $\begin{array}{l}\text { Tambah Data } \\
\text { pembayaran pajak (data } \\
\text { yang diinput tidak } \\
\text { lengkap, kemudian klik } \\
\text { simpan) }\end{array}$ & $\begin{array}{l}\text { Nama Karyawan : (Vita) } \\
\text { Alamat : (Jl. A. Yani) } \\
\text { No HP : (082254783105) }\end{array}$ & $\begin{array}{l}\text { Sistem akan menyimpan } \\
\text { dan menampilkan pesan } \\
\text { "Datar Berhasil } \\
\text { Disimpan" }\end{array}$ & $\begin{array}{c}\text { Sesuai } \\
\text { Harapan }\end{array}$ & Valid \\
\hline 6 & $\begin{array}{l}\text { Tambah Data } \\
\text { pembayaran pajak (data } \\
\text { yang diinput tidak } \\
\text { lengkap, kemudian klik } \\
\text { simpan) }\end{array}$ & Hapus & $\begin{array}{l}\text { Sistem akan memberi } \\
\text { pilihan dengan pesan } \\
\text { "Apakah } \\
\text { menghapus data ?: jika } \\
\text { pilih 'ok' maka data } \\
\text { akan dterhapus. Jika } \\
\text { pilih 'cancel' maka data } \\
\text { tidak terhapus }\end{array}$ & $\begin{array}{c}\text { Sesuai } \\
\text { Harapan }\end{array}$ & Valid \\
\hline 7 & $\begin{array}{l}\text { Tambah Data } \\
\text { pembayaran pajak (data } \\
\text { yang diinput tidak } \\
\text { lengkap, kemudian klik } \\
\text { simpan) }\end{array}$ & Mencetak & $\begin{array}{l}\text { Sistem akan menerima } \\
\text { dan akan tercetak } \\
\text { laporan perhitungan }\end{array}$ & $\begin{array}{c}\text { Sesuai } \\
\text { Harapan }\end{array}$ & Valid \\
\hline
\end{tabular}

\section{PENUTUP}

Penelitian ini dapat disimpulkan sebagai berikut:

1. Sebagian besar karyawan belum mengerti dalam melakukan Perhitungan PPh 21 dan PPh 26 Karyawan sehingga mereka harus melakukan perhitungan secara manual atau dibantu oleh konsultan pajak agar mengetahui berapa jumlah nominal yang harus mereka bayar.

2. Aplikasi perhitungan PPh 21 dan PPh 26 Karyawan Berbasis Web akan mempermudah perusahaan dalam melakukan transakasi pembayaran pajak. aplikasi ini memberikan menu data karyawan, data pengguna dan data pembayaran pajak yang sangat mudah dipahami oleh karyawan atau wajib pajak dalam melakukan transaksi pembayaran. 
3. Website ini dapat membantu pengguna menghitung berapa tarif biaya pembayaran pajak yang akan dikeluarkan dalam waktu yang ditentukan oleh pengguna atau karyawan.

\section{UCAPAN TERIMA KASIH}

Terima kasih kami ucapkan kepada seluruh pihak terkait atas terlaksananya penelitian ini, terutama kepada Allah swt, serta kepada pihak penerbit yang telah berkenan untuk menerbitkan paper ini.

\section{REFERENSI}

[1] Ginting, G. L., \& Napitupulu, D. P. (2018). Perancangan Aplikasi Pendeteksi Kesalahan Perintah SQL Query Menggunakan Algoritma Knuth Morris Pratt. JURIKOM (Jurnal Riset Komputer), 5(4), 377-381.

[2] Yulia, dkk. 2020. Sistem Informasi Penjualan Produk Pontimarket. Jurnal Khatulistiwa Informatika. Vol (8). No (1). p-ISSN: 2339-1928 I e-ISSN: 2579-633X.

[3] Sukamto, R. A., \& Shalahuddin, M. 2015. Kolaborasi Rekayasa Perangkat Lunak Terstruktur dan Berorientasi Objek. Bandung: Informatika. 